\title{
Spontaneous and Induced Abortions and Its Determinants in Women Aged 15-49
}

\section{5-49 Yaş Kadınlarda Kendiliğinden ve İsteyerek Düşükler ve Belirleyicileri}

\author{
${ }^{1}$ Meral ÇETINKAYA, ${ }^{2}$ Yeliz MERCAN
}

\begin{abstract}
Aim: Abortions, which are among the causes of maternal mortality in the world, continue to be important not only for women's health, but also because they have devastating physiological, psychological, and economic effects on the family and society. The present study aimed to determine the prevalence of total, induced, and spontaneous abortion in women aged 15-49 in a Family Health Center (FHC) region, and the factors affecting the abortion prevalence. Methods: This cross-sectional study was conducted with 311 women aged 15-49 registered between February and December 2017 at the FHC region in Northwest Thrace in Turkey. Results: The unintended pregnancy prevalence of the participants was $14.8 \%$, and abortion prevalence was $22.2 \%$. Spontaneous and induced abortions prevalence was $12.2 \%$ and $10.9 \%$, respectively. According to the multivariate logistic regression analysis, the likelihood of abortion was significantly higher than the reference category in those who perceived their income at a bad level, current smokers, and those who considered abortion as a family planning method used to avoid unwanted pregnancies $(\mathrm{p}<0.05)$. The likelihood of induced abortion was significantly higher in women who perceived their income at a bad level, those with spouses aged 35 and older, and those whose spouses had primary school and lower levels of education $(\mathrm{p}<0.05)$. The likelihood of spontaneous abortion in women was higher in each one-unit increase in the total number of pregnancies, compared to those with high-school education, and those who perceived their income at a bad level $(p<0.05)$. Conclusion: Nearly one out of every five women had undesired pregnancy experience, and one out of every four women had abortion experience. Spontaneous abortion prevalence was higher than that of induced abortion. Some sociodemographic and/ or obstetric characteristics are determinants of total abortion, induced abortion, and spontaneous abortion. Keywords: Abortion; Spontaneous abortion; Induced abortion; Unintended pregnancies.
\end{abstract}

\section{ÖZET}

Giriş: Dünyada anne ölüm nedenleri arasında yer alan düşükler sadece kadın sağlığı değil aynı zamanda aile ve toplum için yıkıcı fizyolojik, psikolojik ve ekonomik etkilere sahip olması nedeniyle önemini sürdürmektedir. Bu araştırmada bir Aile Sağlığı Merkezi (ASM) bölgesinde yaşayan 15-49 yaş kadınlarda toplam, isteyerek ve kendiliğinden düşük prevalansını belirlemek ve düşük prevalansını etkileyen faktörleri saptamak amaçlandı. Yöntem: Bu kesitsel çalışma, Şubat ve Aralık 2017 tarihleri arasında Türkiye'de Kuzeybatı Trakya'daki bir ASM bölgesinde kayıtlı 15-49 yaş arası 311 kadın ile yürütüldü. Bulgular: Katılımcıların istenmeyen gebelik prevalansı $\% 14,8$, düşük prevalansı $\% 22,2$ idi. Kendiliğinden ve isteyerek düşük prevalansları sırasıyla \%12,2 ve \%10,9 idi. Katılımcıların \%79,3'ü kürtajın, \%52,1'i ertesi gün hapının bir aile planlaması yöntemi olmadığını ve \%46,2'si Türkiye'de kürtajın yasal olduğunu bilmekteydi. Çok değişkenli lojistik regresyon analizine göre, kadınlarda düşük görülme olasılığı gelirini kötü düzeyde algılayanlarda, sigara içenlerde ve düşüğü istenmeyen gebeliklerden kaçınmak için kullanılan bir aile planlaması yöntemi olarak görenlerde referans kategoriye göre yüksekti $(\mathrm{p}<0,05)$. Kadınlarda isteyerek düşük görülme olasılığı gelirini kötü düzeyde algılayanlarda, eşinin yaşı 35 ve daha büyük olanlarda ve eşinin eğitim düzeyi ilkokul ve daha düşük düzeyde olanlarda anlamlı düzeyde yüksekti $(\mathrm{p}<0,05)$. Kadınlarda kendiliğinden düşük görülme olasılığı toplam gebelik sayısındaki her bir artışta, lise düzeyinde eğitimi olanlarda, gelirini kötü düzeyde algılayanlarda yüksek bulundu ( $<<0,05$ ). Sonuç: Yaklaşık her beş kadından birine yakını istenmeyen gebelik deneyimi, her dört kadından birine yakını kürtaj deneyimi yaşamıştır. Kendiliğinden düşük sıklığı, isteyerek düşük sıklığından yüksek düzeydedir. Bazı sosyodemografik ve / veya obstetrik özellikler toplam düşük, isteyerek düşük ve spontan düșüklerin belirleyicileridir.

Anahtar kelimeler: Düşük; Kendiliğinden düşük; İsteyerek düşük; İstenmeyen gebelik.

Received / Geliş tarihi: 12.03.2021, Accepted / Kabul tarihi: 19.04.2021

${ }^{1}$ Kirklareli University Health Sciences Institute Department of Public Health, Kirklareli, Turkey. celik-meral@hotmail.com ORCID: 0000-0002-7460-0346

${ }^{2}$ Kirklareli University Faculty of Health Sciences Department of Health Management, Kirklareli, Turkey. mercan.yeliz@gmail.com ORCID: 0000-0002$7099-4536$

*Address for Correspondence / Yazışma Adresi:

Kirklareli University Faculty of Health Sciences Department of Health Management, 39000 Kirklareli, Turkey.

Email: mercan.yeliz@gmail.com, Phone: +90 (507)2392995

ÇETINKAYA M, MERCAN Y. Spontaneous and Induced Abortions and Its Determinants in Women Aged 15-49. TJFMPC, 2021;15(3): 490-500.

DOI: $10.21763 /$ tjfmpc.895883 


\section{INTRODUCTION}

The World Health Organization (WHO) defines reproductive health as the satisfying and safe sexual life in addition to the definition of health, having the ability to reproduce, and have the freedom to decide when and at which frequency to do so. ${ }^{1}$ The effect of abortion on health depends on whether it is performed safely or not. Pregnancies that are terminated by people who do not have the necessary skills or in a setting that does not meet the minimum medical standards can cause disruptive physiological, psychological, and economic effects not only for the woman but also for the family and the society. ${ }^{2}$

There are a variety of clinical conditions as the reasons for abortions like spontaneous and induced abortion, incomplete abortion, and intrauterine fetal demise. ${ }^{3}$ The causes of spontaneous abortions include embryonic chromosomal anomalies, genetics, anatomical and endocrine causes, infections, chemicals, cytotoxic drugs, radiation, traumas or stress, psychological problems like anxiety., ${ }^{4,5}$ The main reason for induced abortion is that the pregnancy is not wanted or wanted for a later time. ${ }^{6}$ Unintended pregnancies caused by the lack of contraceptive methods or due to the misuse of effective contraceptive methods and those occurring at a greater rate because of unmet needs also show a lack of healthcare service delivery., 5 In developed countries, despite the contraceptive prevalence observed at a high rate compared to undeveloped and underdeveloped countries, the unmet needs were reported between $7 \%$ and $22 \%$ in the world in $2017 .{ }^{8}$ In Turkey, this rate was $12 \%$ in $2018 .{ }^{9}$ Factors like very young or advanced age, educational level of the mother and/or spouse, working status, profession, low income, rural life, social class, young marriage age, pregnancy, birth and living children count, birth intervals are decisive in this respect. ${ }^{7,10,11}$

There were approximately 56 million induced abortions (safe and unsafe) in the world between 2010 and 2014, and although 35 induced abortions were detected between the ages of 15 and 44 were reported in 1.000 women, $25 \%$ of all pregnancies resulted in induced abortions. This rate was higher in developing countries, and about 25 million women had abortions, and 8 million of these were reported to occur in dangerous conditions. ${ }^{12}$ According to the Turkey Demographic and Health Survey (TDHS) 2018, about two out of five married women had an abortion in Turkey, which were about one in five women in 100 pregnancies. A total of $22.4 \%$ of each married woman had a spontaneous abortion, and $15 \%$ had induced abortion. There was a decrease in the number of induced abortions in Turkey in the past two decades, and the number of spontaneous abortions increased. ${ }^{9}$

It was reported that maternal mortality due to unsafe abortions occurred between $4.7 \%$ and $13.2 \%$ each year. WHO reports that 30 out of every 100,000 women in developed regions, 220 out of every 100,000 women in developing regions, and 520 out of every 100,000 women in sub-Saharan Africa die due to unsafe abortions. ${ }^{12}$ The political position of the country and legal obstacles in this field, fear of being stigmatized, religious beliefs, lack of family support, limited right of women to decide are among the reasons that make it difficult to access safe healthcare services in societies in this field. ${ }^{13-15}$

Ending the unintended pregnancies with abortions leads to an increase in unsafe abortion rates, and insufficient prenatal and postnatal care when results in childbirth, and both cases, cause an increase in mortality and morbidity in women. ${ }^{7,16}$ At the present time, abortions remain to be a major public healthcare problem because it is one of the biggest causes of maternal deaths all over the world, it is continued to be performed in unsafe conditions by uneducated people., ${ }^{9,12,14}$ To our knowledge, no studies were conducted on abortions in Kirklareli, located in the northwest of Turkey. In the current study, we aimed to determine the total abortion, induced abortion, and spontaneous abortion prevalence of women aged 15-49 years and also to determine the factors affecting abortion prevalence in a Family Health Center (FHC) region.

\section{METHODS}

\subsection{Study design}

This cross-sectional study was conducted in Pinarhisar District of Kirklareli between February and December 2017. The universe of the study consisted of 15-49-year-old women registered at the Family Health Center (FHC). The minimum sample size of the study was calculated as $296(\mathrm{~N}=1275, \mathrm{p}$ $=0.50, \alpha=0.05, \mathrm{~d}=0.05)$ in the Epi Info 7.2 program. However, considering the possibility of refusals, withdrawals and/or losses, it was decided to include $10 \%$ more people; thus, it was aimed to reach 326 disabled people. The study included 311 women who were registered at the FHC between the ages of 15-49, with the cognitive capability to answer questions, which completed the survey form and volunteered to participate in the study.

\subsection{Data collection}

The purpose of the study was explained to the women admitting to FHC for any reason. When 
women agreed to participate in the study, they signed informed consent statements. The interviews were conducted in a room allocated to interviews in the FHC, and the forms were filled in by the interviewer or by the interviewee and lasted approximately 40 minutes. Each of the women who presented to the FHC was interviewed just once when they were first contacted. The data were collected by the researchers with the help of the Information Form, which was developed based on the literature. In the first part of the questionnaire form, there were questions on the descriptive characteristics of the participants, and the second part contained questions about obstetric characteristics, abortion experience, and knowledge about abortion.

\subsection{Study variables}

The dependent variables of the study were total abortion experience, induced abortion experience, and spontaneous abortion experience. The participants were first asked, "Have you ever had an abortion?". Those who said "Yes" were asked "How did this abortion happen?" According to the responses, those who said "induced abortion" were evaluated the "induced abortion prevalence", and those who said they had "spontaneous abortion" were evaluated the "spontaneous abortion prevalence". The total prevalence of spontaneous and induced abortions made up the "total abortion prevalence". The descriptive characteristics of the participants such as age, educational status, family type, working status, perceived income level, smoking status, age of spouse, educational status of spouse, working status of spouse constituted the independent variables. Also, the data on the knowledge of the participants on obstetric characteristics like the total number of pregnancies, unintended pregnancy experience, whether abortion or the morning-after pill was not a family planning method, whether abortion was legal or not in Turkey were the other independent variables.

\subsection{Data Analysis}

The numbers (n), percentages (\%), mean, and standard deviation $( \pm$ SD), median values from descriptive tests were used in the analyses. The Pearson Chi-Square Test and Fisher's Exact ChiSquare Test were used for the comparisons of the rates in independent groups. Multivariate Logistic Regression Analysis was performed (Enter strategy). The explanatory value of the models was evaluated with the Nagelkerke R-square $\left(\mathrm{R}^{2}\right)$. $p$ value $<0.05$ was considered statistically significant. The analysis was performed using the Statistical Package for the Social Sciences, version 22.0 (SPSS Inc., Chicago, IL, USA).

\subsection{Ethics Approval}

Ethics approval was obtained from the Ethics Committee of the Institute of Health Sciences at Kirklareli University (10.02.2017- PR26R00), and official permission from the relevant institutions.

\section{RESULTS}

The distribution of some descriptive characteristics of the participants was presented in Table 1. The average age of the participants was $33.52 \pm 7.13$ (Min: 18, Max: 49) and the average number of pregnancies was $1.43 \pm 1.27$ (Min: 0, Max: 6, Median: 1). The unintended pregnancy prevalence of the participants was $14.8 \%$, and the abortion prevalence was $22.2 \%$. A total of $10.9 \%$ of the women had induced abortion, and had $12.2 \%$ spontaneous abortion. A total of $79.3 \%$ of participants knew that abortion was not a method of family planning, and $52.1 \%$ knew that the morningafter pill was not a method of family planning, and $46.2 \%$ knew abortion was legal in Turkey (Table 1). 
Table 1. Distribution of some descriptive characteristics of the participants $(n=311)$.

\begin{tabular}{|c|c|c|}
\hline Variables & $\mathbf{n}$ & $\%$ \\
\hline \multicolumn{3}{|l|}{ Age } \\
\hline$<35$ & 174 & 55.9 \\
\hline$\geq 35$ & 137 & 44.1 \\
\hline \multicolumn{3}{|l|}{ Educational status } \\
\hline University and above & 140 & 45.0 \\
\hline Secondary school and High-school & 125 & 40.2 \\
\hline Primary school and below & 46 & 14.8 \\
\hline \multicolumn{3}{|l|}{ Family type } \\
\hline Nuclear & 266 & 85.5 \\
\hline Fragmented \& Extended & 45 & 14.5 \\
\hline \multicolumn{3}{|l|}{ Working status } \\
\hline Yes & 157 & 50.5 \\
\hline No & 154 & 49.5 \\
\hline \multicolumn{3}{|l|}{ Perceived income level } \\
\hline Good & 132 & 42.4 \\
\hline Moderate & 166 & 53.4 \\
\hline Bad & 13 & 4.2 \\
\hline \multicolumn{3}{|l|}{ Smoking status } \\
\hline No & 231 & 74.3 \\
\hline Yes & 80 & 25.7 \\
\hline \multicolumn{3}{|l|}{ Age of spouse } \\
\hline$<35$ & 82 & 35.7 \\
\hline$\geq 35$ & 148 & 64.3 \\
\hline \multicolumn{3}{|l|}{ Educational status of spouse } \\
\hline Secondary school and above & 203 & 85.7 \\
\hline Primary school and below & 34 & 14.3 \\
\hline \multicolumn{3}{|l|}{ Working status of spouse } \\
\hline Yes & 232 & 97.9 \\
\hline No & 5 & 2.1 \\
\hline \multicolumn{3}{|l|}{ Total number of pregnancies } \\
\hline 0 & 95 & 30.5 \\
\hline $1-2$ & 158 & 50.8 \\
\hline$\geq 3$ & 58 & 18.6 \\
\hline \multicolumn{3}{|l|}{ Unintended pregnancy } \\
\hline Yes & 46 & 14.8 \\
\hline No & 265 & 85.2 \\
\hline \multicolumn{3}{|l|}{ Abortion } \\
\hline Yes & 69 & 22.2 \\
\hline No & 242 & 77.8 \\
\hline \multicolumn{3}{|l|}{ Induced abortion } \\
\hline Yes & 34 & 10.9 \\
\hline No & 277 & 89.1 \\
\hline \multicolumn{3}{|l|}{ Spontaneous abortion } \\
\hline Yes & 38 & 12.2 \\
\hline No & 273 & 87.8 \\
\hline \multicolumn{3}{|c|}{ Is abortion a family planning method used to avoid unintended pregnancies? } \\
\hline Yes & 64 & 20.7 \\
\hline No & 245 & 79.3 \\
\hline \multicolumn{3}{|c|}{$\begin{array}{l}\text { Is morning-after pill a family planning method used to avoid unintended } \\
\text { pregnancies? }\end{array}$} \\
\hline Yes & 149 & 47.9 \\
\hline No & 162 & 52.1 \\
\hline \multicolumn{3}{|l|}{ Is abortion legal in Turkey? } \\
\hline Yes & 140 & 46.2 \\
\hline No, I do not know & 163 & 53.8 \\
\hline
\end{tabular}


A total of $21.7 \%$ of the women had abortions to their medical problems, and $17.4 \%$ due to the medical health problems of their baby. Other reasons included spousal violence, having a sufficient number of children, etc. (Figure 1).

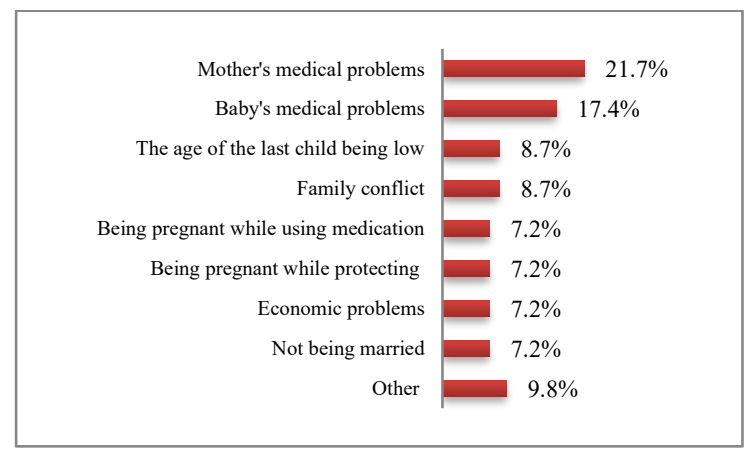

Figure 1. Reasons for participants to have an abortion $(n=69)$.

Women knew that abortion was allowed in Turkey when pregnancy threatens the life of the mother (50.2\%), fetal causes $(46.9 \%)$, and rape/incestuous $(37.3 \%)$. The rate of those who knew that it was allowed upon desire and due to any reason was $7.1 \%$ (Figure 2 ).

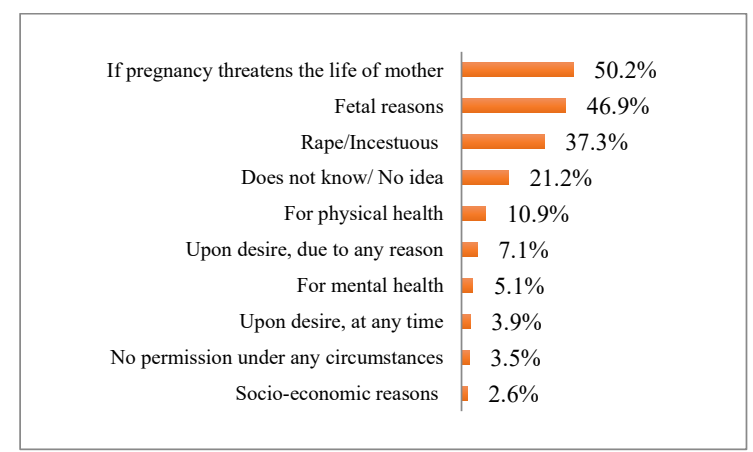

Figure 2. Participants' knowledge about the situations in which abortion is allowed in Turkey $(n=311)$.

The comparison of abortion prevalence according to some descriptive characteristics of the participants was presented in Table 2 .

The participants' multivariate logistic regression analysis of total abortion, induced abortion, and spontaneous abortion prevalence were given in Table 3, Table 4, and Table 5. In the model in which the Enter Strategy was used, $13.8 \%$, $22.2 \%$, and $30 \%$ of the variance were explained in the total abortion, induced abortion, and spontaneous abortion according to Nagelkerke $\mathrm{R}^{2}$, respectively. The likelihood of total abortion was higher in women who perceived their income at a bad level (OR: 6.27, 95\% CI: 1.55; 25.30), who smokers (OR: 1.96, 95\% CI: 1.06; 3.60), and those who know abortion as a family planning method used to avoid unwanted pregnancies (OR: 2.43, $95 \%$ CI: $1.29 ; 4.58$ ) than other categories (Table 3 ).

The likelihood of induced abortion was higher in women who perceived their income at a bad level (OR: 28.70, 95\% CI: 2.84; 290.17), whose spouses were 35 and older of age (OR: 2.97, $95 \%$ CI: $1.09 ; 8.12$ ), and of whom spouses with education level in primary school and lower levels (OR: 3.42 , 95\% CI: $1.10 ; 10.63$ ) than other categories (Table 4).

The likelihood of spontaneous abortion in women with each increase in the number of total pregnancies (OR: 2.22, 95\% CI: $1.54 ; 3.22$ ), in those with high-school education level (OR: 6.69, 95\% CI: 1.77 ; 25.32), those who perceived income at a bad level (OR: 10.49, 95\% CI: 2.02; 54.59) were higher than in other categories of variables (Table 5). 
Table 2. Comparison of abortion prevalence according to some descriptive characteristics of the participants $(\mathrm{n}=311)$.

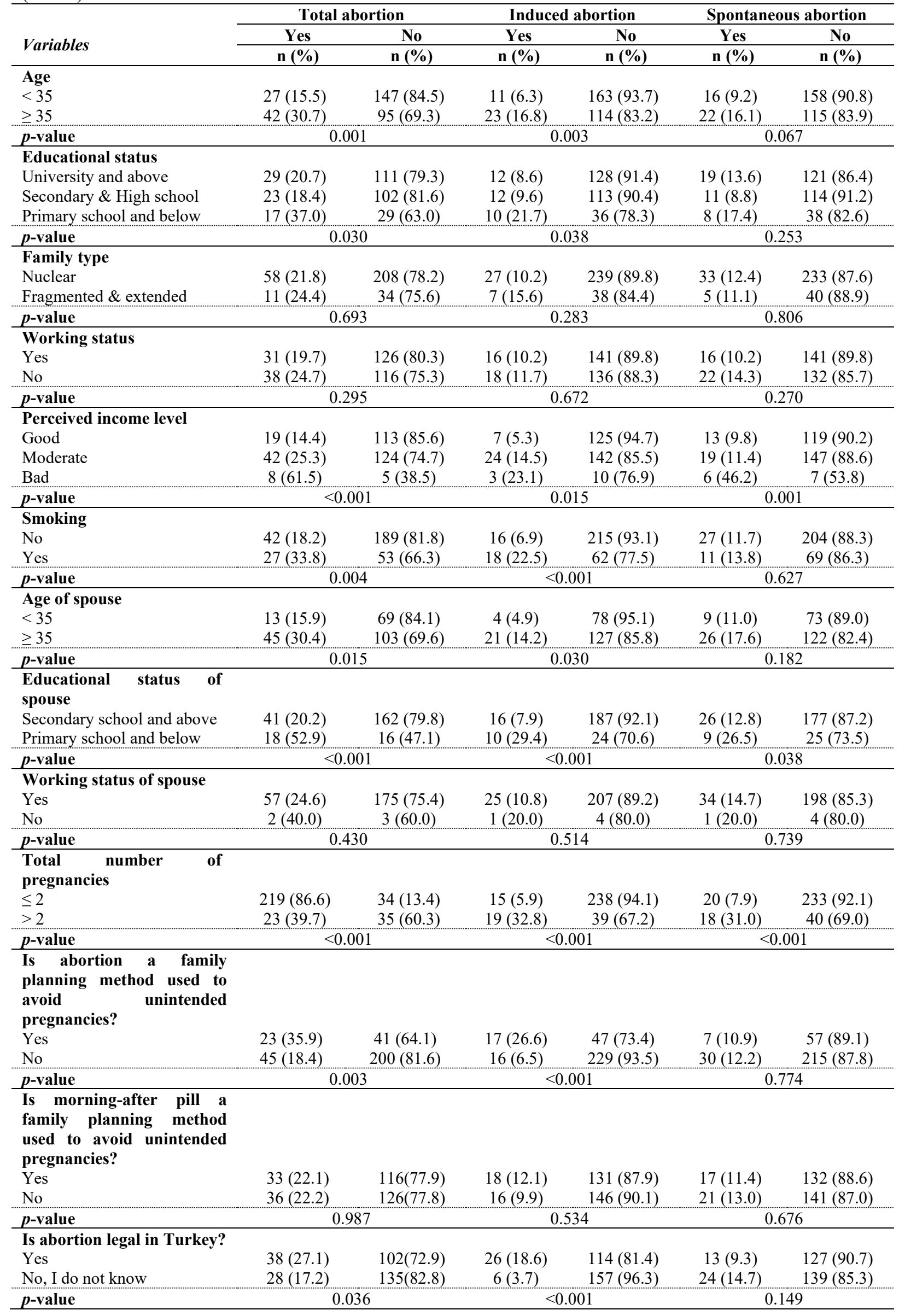


Table 3. Multivariate logistic regression analysis of total abortion prevalence

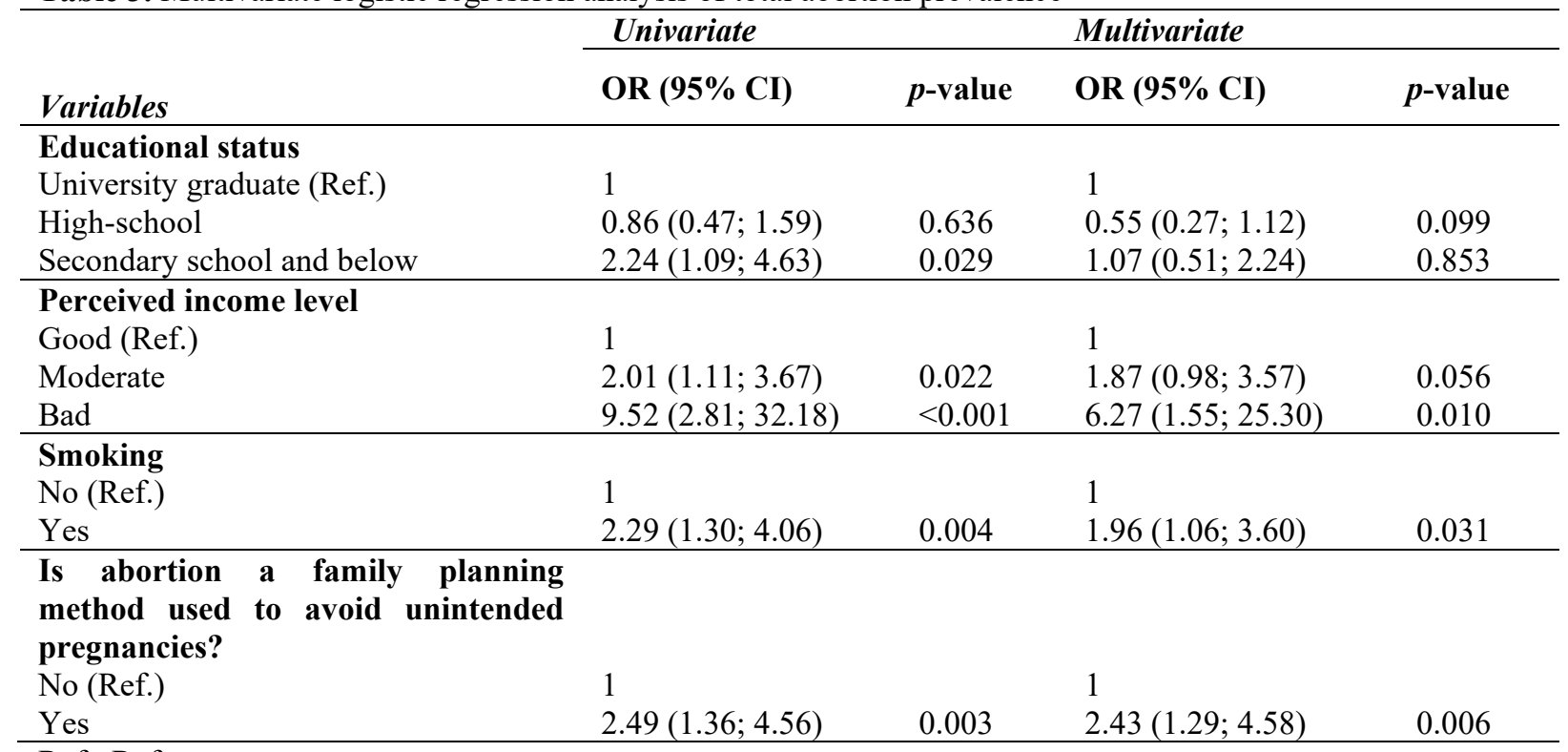

Ref.: Reference category.

Table 4. Multivariate logistic regression analysis of induced abortion prevalence

\begin{tabular}{|c|c|c|c|c|}
\hline \multirow[b]{2}{*}{ Variables } & \multicolumn{2}{|l|}{ Univariate } & \multicolumn{2}{|l|}{ Multivariate } \\
\hline & OR $(95 \%$ CI) & $p$-value & OR $(95 \% \mathrm{CI})$ & $p$-value \\
\hline Age & $1.09(1.04 ; 1.15)$ & 0.001 & $0.97(0.90 ; 1.05)$ & 0.478 \\
\hline \multicolumn{5}{|l|}{ Educational status } \\
\hline University graduate (Ref.) & 1 & & 1 & \\
\hline High-school & $0.95(0.37 ; 2.41)$ & 0.911 & $2.31(0.69 ; 7.69)$ & 0.173 \\
\hline Secondary school and below & $2.53(1.10 ; 5.81)$ & 0.028 & $1.07(0.35 ; 3.30)$ & 0.911 \\
\hline \multicolumn{5}{|l|}{ Perceived income level } \\
\hline Good (Ref.) & 1 & & 1 & \\
\hline Moderate & $3.02(1.26 ; 7.24)$ & 0.013 & $1.51(0.71 ; 3.24)$ & 0.286 \\
\hline Bad & $5.36(1.20 ; 23.96)$ & 0.028 & $28.70(2.84 ; 290.17)$ & 0.004 \\
\hline \multicolumn{5}{|l|}{ Smoking status } \\
\hline No (Ref.) & 1 & & 1 & \\
\hline Yes & $3.90(1.88 ; 8.10)$ & $<0.001$ & $1.78(0.83 ; 3.82)$ & 0.136 \\
\hline \multicolumn{5}{|l|}{ Age of spouse } \\
\hline$<35$ (Ref.) & 1 & & 1 & \\
\hline$\geq 35$ & $3.22(1.07 ; 9.74)$ & 0.038 & $2.97(1.09 ; 8.12)$ & 0.034 \\
\hline \multicolumn{5}{|l|}{ Educational status of spouse } \\
\hline Secondary school and above (Ref.) & 1 & & 1 & \\
\hline Primary school and below & $4.87(1.99 ; 11.94)$ & 0.001 & $3.42(1.10 ; 10.63)$ & 0.033 \\
\hline \multicolumn{5}{|c|}{$\begin{array}{l}\text { Is abortion a family planning } \\
\text { method used to avoid unintended } \\
\text { pregnancies? }\end{array}$} \\
\hline No (Ref.) & 1 & & 1 & \\
\hline Yes & $5.18(2.44 ; 10.98)$ & $<0.001$ & $1.76(0.82 ; 3.77)$ & 0.148 \\
\hline
\end{tabular}

Ref.: Reference category. 
Table 5. Multivariate logistic regression analysis of spontaneous abortion prevalence of participants

\begin{tabular}{lllll}
\hline & Univariate & \multicolumn{2}{c}{ Multivariate } \\
\cline { 2 - 5 } Variables & OR (95\% CI) & $\boldsymbol{p}$-value & OR (95\% CI) & $\boldsymbol{p}$-value \\
\hline Educational status & & & & \\
University graduate (Ref.) & $0.49(0.20 ; 1.22)$ & 0.124 & $6.69(1.77 ; 25.32)$ & 0.005 \\
High-school & $1.25(0.57 ; 2.75)$ & 0.574 & $2.03(0.58 ; 7.11)$ & 0.270 \\
Secondary school and below & 1 & & & 0.949 \\
\hline Perceived income level & $1.18(0.56 ; 2.49)$ & 0.658 & $1.03(0.43 ; 2.44)$ & 0.005 \\
Good (Ref.) & $7.85(2.29 ; 26.89)$ & 0.001 & $10.49(2.02 ; 54.59)$ & $<0.001$ \\
Moderate & $2.12(1.59 ; 2.82)$ & $<0.001$ & $2.22(1.54 ; 3.22)$ & \\
Bad & & & &
\end{tabular}

\section{DISCUSSION}

In this study, which was conducted with 15-49 years old 311 women in an FHC region in Kirklareli in the northwest of Turkey, it was found that nearly one out of every five women had unintended pregnancies. In studies conducted in the United States of America, Iran and Ethiopia, it was reported that the unintended pregnancy prevalence was between $20 \%$ and $45 \% .{ }^{17-19}$ According to the results of the TDHS in $2018,15 \%$ of the births were unintended, and $11 \%$ were desired later. ${ }^{9}$ These results, which were found to be relatively lower, may have been due to regional differences in the study. As a matter of fact, in Kirklareli, which was located in northwestern Turkey, it was found that nearly one in every four women had at least one abortion in their lives. More than one in ten women had a spontaneous abortion, and about one in ten had induced abortion. A study conducted in India reported that $33 \%$ of unintended pregnancies resulted in induced abortion. ${ }^{10}$ Kant et al. reported that $11 \%$ of the pregnancies resulted in abortion, the spontaneous abortion rate was $7.2 \%$, and the induced abortion rate was $3.8 \% .{ }^{20}$ According to TDHS 2018 data in our country, $22.4 \%$ of every woman married had a spontaneous abortion, and $15 \%$ had induced abortion. ${ }^{9}$ It was determined that our prevalence was lower than national-level studies. This was explained by the fact that nearly half of the participants were university-graduate women. It was associated with the high awareness levels and the success of the use of family planning methods for pregnancy risks as the multiplier effect of the education in highly educated people. As a matter of fact, in the other finding of the study, the educational status was found to be determinant of the prevalence of spontaneous abortion. In studies conducted in Brazil, Kenya, and Turkey, which support our findings, the abortion rate was reported to be higher in people with lower educational levels. ${ }^{21-23}$
It is known that smoking during pregnancy affects fetal and neonatal development, infant and child health, and is associated with adverse pregnancy outcomes such as placenta previa, abruptio placenta, premature rupture of membranes, perinatal mortality and ectopic pregnancy. ${ }^{24}$ In the study, the total miscarriage probability was found 1.96 times higher for smokers than non-smokers. Consistent with our result, Pineles et al. found 1.23 times (\%95 CI: 1.16, 1.30) higher in active smokers in the systematic review and meta-analysis they conducted, and it was shown that exposure to cigarette smoke during pregnancy increased the risk of miscarriage by $11 \%{ }^{25}$

The WHO reported that women and poor women who had low-income levels were more likely to have an unsafe abortion. ${ }^{9}$ It was also determined in the study that perceived income level was decisive in total abortion, spontaneous and induced abortion prevalence. It was reported in a study conducted in Brazil that women without lifelong abortions had an average income of $\$ 241$ per person, while those who had an abortion had an income of $\$ 173.6$ per capita. ${ }^{23}$ In a study conducted on Spanish women also reported that abortion levels were higher in women with low-income levels. ${ }^{26}$ Other studies conducted in the literature also showed that the majority of abortions were detected in women with low-income levels..$^{5,7,11}$ It was found that our results support the literature.

The current study revealed that the age of the spouse and spouse's educational status were significant in the frequency of induced abortion. A study conducted abroad reported that those with spouses of advanced age had high induced abortion rates. ${ }^{20}$ Gunyeli et al. conducted a study in Turkey in Isparta, Ankara, and Istanbul on women applying for family planning and abortion services and compared the ages of the spouses of these women, reporting that the ages of these women were 
higher. ${ }^{27}$ Studies conducted in Portugal and India reported that most of the spouses of the women who had an abortion had low education levels. ${ }^{20,28}$ It was observed in studies conducted in our country that the spouses of the women with an unintended pregnancy or induced abortion experience were mostly primary school graduates or had low educational levels. ${ }^{5,27}$ This finding, which supports the literature, might have increased the tendency of spouses to have induced abortions due to economic concerns and having enough children. It was also considered that it might have stemmed from the fact that the man still has a say on the body of women in society and that women may not have enough to say in society.

In our study, the probability of spontaneous abortion in women was increased at significant levels with each one-unit increase in the total number of pregnancies. A study conducted in China reported that women with 1-2 live births were twice as high as women who had never given live births. $^{18}$ It was reported in previous studies conducted abroad and in our country that there was an increased risk in an increased number of births, and the number of living children. ${ }^{20,21,29,30}$ It was found that our results support the literature.

In this study that four out of five women knew that abortion, more than half knew that the morning-after pill was not a family planning method. In addition, the study found that those who thought abortion was a family planning method used to avoid unwanted pregnancies had a high probability of abortion. In a study in Brazil, Souza et al. found that about one-fifth of women with induced abortion did not use any contraceptive methods, although they did not want to have children. ${ }^{31}$ Ilboudo et al. conducted a study in Burkina Faso and reported that $68 \%$ of women who had induced abortion previously had abortions, and $80 \%$ of women did not use a method for family planning. ${ }^{32}$ A total of $7.7 \%$ of the women admitting to a hospital in Konya İn Turkey for abortion considered abortion as a method of family planning, and the prevalence of these women with multiple abortions was found to be significantly higher. ${ }^{33}$ This finding of ours, which was in line with the literature, showed the lack of healthcare services delivery and revealed the gap in knowledge about family planning methods of women. It was found out in the present study that more than half of the participants did not know that abortion was legal in Turkey. In a study conducted at a university hospital, it was found that only about one-fifth of the participants considered abortion as a natural right, two-thirds approved in case of danger for health, and more than one in ten people wanted strictly that it would not be allowed under any circumstances. $^{34}$ In the first 10-12 weeks of the pregnancy, induced abortion was considered as part of the reproductive rights, preventing abortions by reducing unintended pregnancies was seen as an important gain for women's health. ${ }^{6}$ This finding of ours suggests that those who know that abortion was legal to use it as a family planning method and also brought about the problem of access to healthcare for women without knowledge. In this sense, the present study showed that the transfer of accurate information to the whole community was important for public healthcare, especially for the health of women and children.

\section{Study Limitations}

Since the study was conducted with women registered at FHC, the fact that women who did not admit to the FHC could not be reached between the study dates, and that the results cannot be generalized to the society were the limitations of the study. The results should be interpreted carefully because the cause-effect relation arising from the study design could not be determined exactly.

\section{Conclusion}

Nearly one out of every five women had unintended pregnancy experience, and one out of every four women had abortion experience. Spontaneous abortion prevalence was higher than induced abortion prevalence. In the present study, four out of five women knew that abortion, and more than half of the women knew that the morning-after pill was not a method of family planning, and about half of the women knew that abortion was legal in Turkey. Some sociodemographic and/ or obstetric characteristics are determinants of total abortion, induced abortion, and spontaneous abortion.

Abortions, especially induced abortions show the inadequacy of healthcare services. For this reason, applications of women to FHC should be considered as an opportunity and efforts should be made to prevent unintended pregnancies. All women should be trained on reproductive health and family planning methods, and individual counseling should be provided, and spouses should also be involved in these programs. It should be emphasized that abortion and the After Morning Pill are not a family planning method, and this misperception in society should be avoided with education. The need for family planning that is not met is an important public healthcare problem because it can cause unintended pregnancy, induced abortion, even mother-baby deaths. For this reason, this need should be met by prioritizing the risk groups in terms of social determinants. The knowledge that abortion is legal in Turkey should be taught, and the legal time limits of the induced abortion should be emphasized. Reproductive healthcare trainings should be provided as of primary school by adopting a lifelong reproductive health approach. 
Acknowledgements: This article was based on the master thesis and was presented as an oral presentation in Izmir in Turkey in 2018, and its full text was published in the proceedings book.

Conflict of Interest: Authors declared no conflict of interest.

Financial Disclosure: None.

\section{REFERENCES:}

1. World Health Organization. Reproductive health. [cited 2020 July 15]. Available from:https://www.who.int/westernpacific/healt h-topics/reproductive-health

2. World Health Organization. Abortion, Health Impact. [cited 2020 July 15]. Available from: https://www.who.int/healthtopics/abortion\#tab=tab_2

3. World Health Organization (2020) Abortion, Overview. [cited 2020 July 15]. Available from: https://www.who.int/healthtopics/abortion\#tab=tab 1

4. Ford HB, Schust DJ. Recurrent Pregnancy Loss: Etiology, Diagnosis, and Therapy. Rev Obstet Gynecol. 2009;2(2):76-83.

5. Dereli Yilmaz S, Ege E, Akin B, Celik C. The reasons of induced abortion and contraceptive preference in 15-49 years women. FNJN. 2010; 18(3):156-163.

6. Hacettepe University Institute of Population Studies. 2013 Turkey Demographic and Health Survey Advanced Analysis Study. Ankara, Turkey, 2015. p.139-223.

7. Santos APV, Cardoso Coelho EA, Neves Gusmao ME, Silva DO, Marques PF, Almeida MS. Factors Associated with Abortion in Women of Reproductive. RBGO. 2016;38(6):273-279.

8. United Nations, Department of Economic and Social Affairs, Population Division. World Family Planning 2017 - Highlights New York, USA, 2017. (ST/ESA/SER.A/414).

9. Hacettepe University Institute of Population Studies. 2018 Turkey Demographic and Health Survey. Ankara, Turkey,2019. p.159-170.
10. Singh S, Shekhar C, Acharya R, Moore AM, Stillman M, Pradhan MR, et al. The incidence of abortion and unintended pregnancy in India, 2015. Lancet Glob Health. 2018;6(1):111-120.

11. Hagos G, Tura G, Kahsay G, Haile K, Grum T, Araya T. Family Planning Utilization and Factors Associated among Women Receiving Abortion Services in Health Facilites of Central Zone Towns of Tigray, Northern Ethiopia: A Cross Sectional Study. BMC Women's Health. 2018;18:83-91.

12. World Health Organization. Preventing unsafe abortion. [cited 2020 July 15]. Available from: https://www.who.int/news-room/factsheets/detail/preventing-unsafe-abortion

13. Cavlin A, Tezcan S, Ergocmen B. Women's perspective on induced abortion. The Turkish Journal of Population Studies. 2012;34:51-67.

14. Gokgol T. A global perspective on abortion: Laws and experiences. Turk J Public Health. 2012;10(1): 1-9.

15. Wokoma TT, Jampala M, Bexhell H, Guthrie KA, Lindow SW. Reasons Provided for Requesting a Termination of Pregnancy in the UK. J Fam Plann Reprod Health Care. 2015;41:186-192.

16. Doganer G, Bilgic D, Doganer A, Umut UF, Kurk H, Celik E. Attitudes and Knowledge Related to the Emergency Contraception of the Women Aged 15-49. DEU E-Journal of Nursing Faculty. 2011;4(4):159-164.

17. Finer LB, Zolna MR. Declines in Unintended Pregnancy in the United States, 2008-2011. N Engl J Med. 2016;374(9):843-52.

18. Omani-Samani R, Rarani MA, Sepidarkish M, Morasae EK, Maroufizadeh S, AlmasiHashiani A. Socioeconomic inequality of unintended pregnancy in the Iranian population: a decomposition approach. BMC Public Health. 2018;18(1):607.

19. Wado YD, Afework MF, Hindin MJ. Unintended pregnancies and the use of maternal health services in Southwestern Ethiopia. BMC Int Health Hum Rights. 2013;13:36

20. Kant S, Srivastava R, Rai SK, Misra P, Charlette L, Pandav SC. Induced abortion in villages of Ballabgarh HDSS: rates, trends, causes and determinants. 2015; Reprod Health. 12:51. 
21. Budak MŞ, Togrul C, Balsak D, Sakar MN, Tahaoğlu AE, Akgöl S, et al. The Evaluation of Failed Contraception Methods and Causes In Elective Pregnancy Termination. The Journal of Gynecology - Obstetrics and Neonatology. 2015;12(3):106-109.

22. Maina BW, Mutua MM, Sidze EM. Factors Associated with Repeat Induced Abortion in Kenya. BMC Public Health. 2015;15:1048.

23. Fusco LBC, Silva RS, Andreoni S. Unsafe abortion: social determinants and health inequities in a vulnerable population in São Paulo, Brazil. Cad Saude Publica. 2012;28(4):709-19.

24. Wolf MF, Bar-Zeev Y, Solt I. Interventions for Supporting Women to Stop Smoking In Pregnancy. Harefuah. 2018 Dec;157(12):783786.

25. Pineles BL, Park E, Samet JM. Systematic review and meta-analysis of miscarriage and maternal exposure to tobacco smoke during pregnancy. Am J Epidemiol. 2014 Apr 1;179(7):807-23. doi: 10.1093/aje/kwt334.

26. González-Rábago Y, Rodriguez-Alvarez E, Borrell LN, Martín U. The Role of Birthplace and Educational Attainment on Induced Abortion Inequalities. BMC Public Health. 2017;17(69):1-7.

27. Gunyeli I, Abike F, Bingol B, Ornek T. Contraceptive counseling in Turkey after induced abortion. Int $\mathrm{J}$ Gynaecol Obstet. 2012;119(2):174-7.

28. Pereira J, Pires R, Pedrosa AA, Vicente L, Bombas T, Canavarro MC. Sociodemographic, sexual, reproductive and relationship characteristics of adolescents having an abortion in Portugal: a homogeneous or a heterogeneous group?. Eur J Contracept Reprod Health Care. 2017;22(1):53-61.

29. Ilboudo PGC, Somda SMA, Sundby J. Key determinants of induced abortion in women seeking postabortion care in hospital facilities in Ouagadougou, Burkina Faso. Int J Womens Health. 2014;6:565-72.

30. Ruiz-Ramos M, Gimeno-Ivanez L, Garcia Leon FJ. Sociodemographic characteristics of induced abortions in Andalusia (Spain): differences between native and foreign populations. Gac Sanit. 2012;26(6):504-11.
31. Souza Goulart M, Fusco LBC, Andreoni SA, Silva RS. Prevalence and sociodemographic characteristics of women with induced abortion in a population sample of São Paulo, Brazil. Rev Bras Epidemiol. 2014;17(2):297-312.

32. Ilboudo PGC, Greco G, Sundby J, Torsvik G, Estimating the costs for the treatment of abortion complications in two public referral hospitals: a cross-sectional study in Ouagadougou, Burkina Faso. BMC Health Serv Res. 2016;16(1):559.

33. Kara F, Bati S, Demir S. Evaluation of Women Applying to a Hospital for Legal Evacuation. 17. National Public Health Congress Book, Edirne, 2014. p. 413-414.

34. Cakmak B, Metin FZ, Ozsoy AZ, Yilmaz Dogru H. Opinion of Women about Deliberate Abortion. Smyrna Med J. 2015;7(1):31-35. 